\title{
IN VITRO INVESTIGATION OF INFLUENCE OF TEMPERATURE RISING ON PERIODONTAL TISSUE DURING ENDODONTIC TREATMENT
}

\author{
Slavcho Dimitrov ${ }^{1}$, Tzvetelina Gueorgieva ${ }^{1}$, Violeta Dogandzhiyska ${ }^{1}$, I. \\ Angelov². \\ 1) Department of Operative dentistry and Endodontics, Faculty of Dental Med- \\ icine, Medical University - Sofia, Bulgaria \\ 2) Institute of Organic Chemistry, Bulgarian Academy of Sciences, Sofia, Bul- \\ garia
}

\section{SUMMARY}

Various manipulations during endodontic treatment and restoration of endodontic treated teeth can be associated with increase of the temperature in dental structure and periodontal tissue. These manipulations include: mechanical root canal preparation, obturation with warm condensation techniques, root - canal preparation for radicular post. The critical level of temperature, that doesn't cause irreversible consequences is $43^{\circ} \mathrm{C}$. The aim of this study is to investigate the temperature changes on external root surface during endodontic treatment depending of dentin thickness. Thirty six single - rooted, human teeth extracted for prosthetic or periodontal reasons were selected for this study. Teeth were divided into four groups-nine teeth in each one. The temperature changes during mechanical root canal preparation, vertical warm condensation, continious wave of condensation and root canal preparation for radicular post are explored and the results are presented.

Key words: temperature changes, external root surface, mechanical root canal preparation, warm condensation techniques for obturation, root canal preparation for radicular post.

\section{INTRODUCTION}

Various manipulations during endodontic treatment and restoration of endodontic treated teeth can be associated with increase of the temperature in dental structure and periodontal tissue. During thermoplastic methods of condensation the plastification of gutta-percha leads to rise of temperature on external and internal root surface $(1,3,6,7)$. This may injure the cementum, periodontal ligament and alveolar bone. It has been found that the alkaline phosphatise in bone can be inactivated at $56^{\circ} \mathrm{C}$, which is a critical temperature for bone damage (1). The same authors report that if the bone structures are exposed to temperature at $50^{\circ} \mathrm{C}$ for 1 minute or $47^{\circ} \mathrm{C}$ for $5 \mathrm{~min}$ utes, the bone will resorb and will be replaced by adipose tissue (1). The other authors announce for periapical inflammation when termoplastificied gutta-percha is injected $-160^{\circ} \mathrm{C}(3)$. It has been accepted that $10^{\circ} \mathrm{C}$ is permitted level of temperature augmentation on external root surface $\left(47^{\circ} \mathrm{C}\right)(3,2)$. The temperature changes on external root surface was investigated during root canal preparation for posts. The results show that during preparation the temperature on external root surface may increase at level that could cause injury of periapical tissue $(2,4$, 5). These manipulations include: mechanical root canal preparation, obturation with warm condensation techniques, root - canal preparation for radicular post. The critical level of temperature, that doesn't cause irreversible consequences is $43^{\circ}$. The analysis of literary data shows discrepancies of the received results of heating the external root surface. In the use of miscellaneous techniques for processing and fulfilling of root canals the warming depends on the sort and the qualities of the instruments used for preparation, their cutting ability, number of revolutions per minute. Have given the importance of discussed issues for the endodontic treatment, the purpose in our study is to investigate the temperature changes on external root surface during endodontic treatment depending of dentin thickness. Thirty six single rooted, human teeth extracted for prosthetic or periodontal reasons were selected for this study. Teeth were divided into four groups-nine teeth in each one. The temperature changes during mechanical root canal preparation, vertical warm condensation, continuous wave of condensation and root canal preparation for radicular post are explored and the results are presented. 
Fig. 1. Experimental setting for thermal study

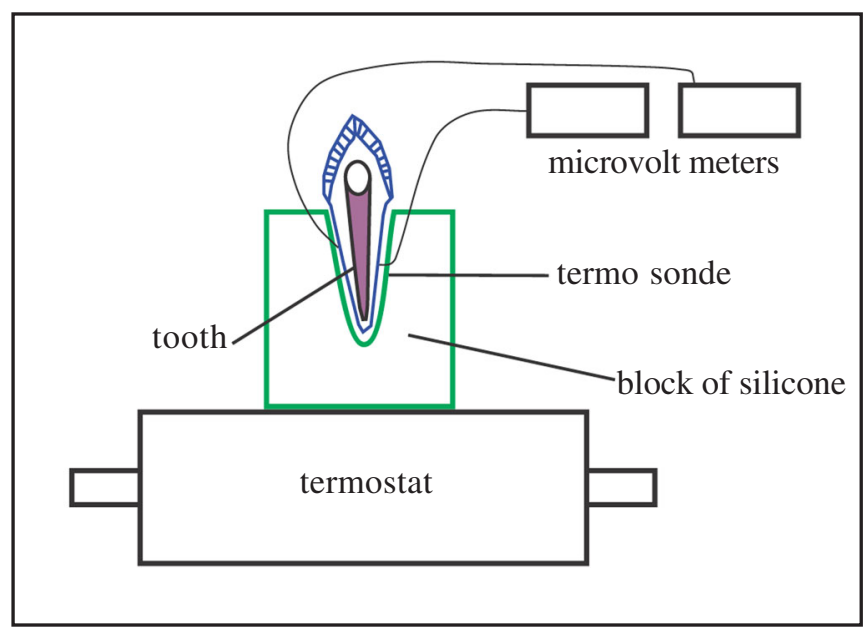

Fig. 2. Raising of temperature on external root surface depending on root dentin thickness during mechanical root-canal preparation with Flex Master

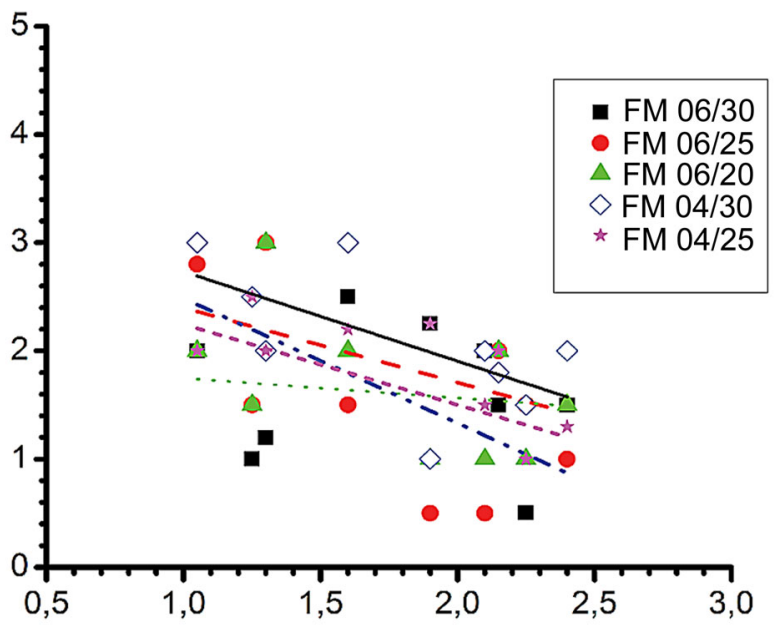

MATERIALS AND METHODS:

Forty single-rooted, human teeth extracted for prosthetic or periodontal reasons were selected for this study. Teeth were divided into four groups-nine teeth in each one. Endodontic cavities were prepared and working length was determined. The root canals were prepared at working length with hand K-file No. 25.Teeth were fixed in silicone canules at the enamel-cement junction/ECJ/ at $36^{\circ} \mathrm{C} \pm 1 \mathrm{C}^{\circ}$. Temperature rise on the root surface was measured using one thermocouple for each tooth, that was fixed 10-11 mm apical from ECJ . The silicon blocks with includ- ed teeth with thermocouples are put on thermostatic camera made for the purpose. The measurement of temperature on external tooth surface at any particular manipulation begins after tempering the entire system up to $36^{\circ} \mathrm{C}+1^{\circ} \mathrm{C}$. The used equipment gave a possibility for detection of temperature changes of dental surface with accuracy next to $0,2^{\circ} \mathrm{C}$.

\section{CONDUCTED EXPERIMENTS :}

Group No. 1: The root canals of teeth from group No. 1 are prepared with endodontic motor Endo IT and Flex master endodontic system at $260 \mathrm{rpm} ; 125 \mathrm{~g} / \mathrm{sm}^{2}$.The samples No. 1, 2, 3, 4, 5 and 6 are prepared with instruments:06/ 30,06/25,06/20 and 04/30; samples No. 7, 8 and 9 with instruments:06/25,06/20,04/30 and $04 / 25$.

Group No. 2: The teeth are prepared the same way as the teeth from group No. 1.The teeth were filled with the continuous wave of condensation technique using a System B Heat Source. The plugger and the gutta-percha cone are adjusted. The heat source was adjusted to $200^{\circ} \mathrm{C}$. The plugger was driven through the gutta-percha cone in the canal to within $3-4 \mathrm{~mm}$ of the binding point, the touch spring was released and then apical pressure was maintained on the plugger in this position for 10 seconds. The heat was activated for 1 seconds and the plugger was removed.

Group No. 3: The teeth were prepared the same way as the teeth from group No. 1 . The root canals were obturated with gutta-percha using injectable technique and $\mathrm{Ob}$ tura II system. The needle was positioned at a distance of $\sim 3 \mathrm{~mm}$ from the apex in order to inject the gutta-percha and vertically compacted with condenser.

Group No. 4: The teeth were prepared the same way as the teeth from group No. 1 and obturated using Obtura II. The root canals were prepared for radicular post with Dental Reamers "NORDIN", H. Nordin SA; CH-1816 Chailly at $600 \mathrm{rpm} ; 217 \mathrm{~g} / \mathrm{cm}^{2}$.

\section{RESULTS, ANALYSIS AND DISCUSSION}

The received values of temperature rise during various manipulations are presented on figure No.No. 2, 3 and 4.

The measuring of the temperature changes during mechanical root-canal preparation with Flex Master files (fig. 2.), root-canal obturation with warm condensation techniques (using System B and Obtura II) (fig. 3.) and rootcanal preparation for radicular post with dental reamers "Nordin", showed that these manipulations are accompanied with raising of temperature on external root surface. 
Fig. 3. Raising of temperature on external root surface depending on root dentin thickness during root-canal obturation with warm condensation techniques (using System B and Obtura II).

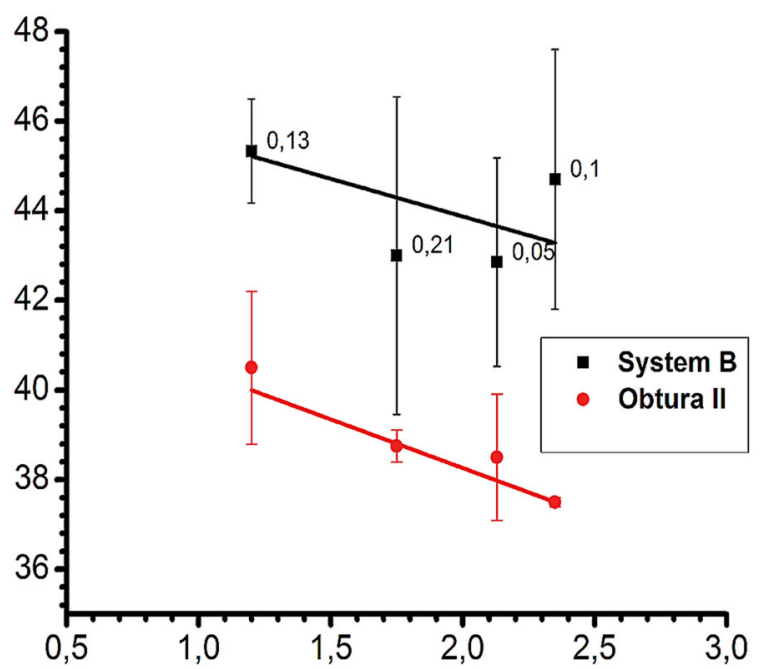

Fig. 4. (a, b, c, d, e, f): Raising of temperature on external root surface depending on root dentin thickness during root-canal preparation for radicular post with different No. No. dental reamers
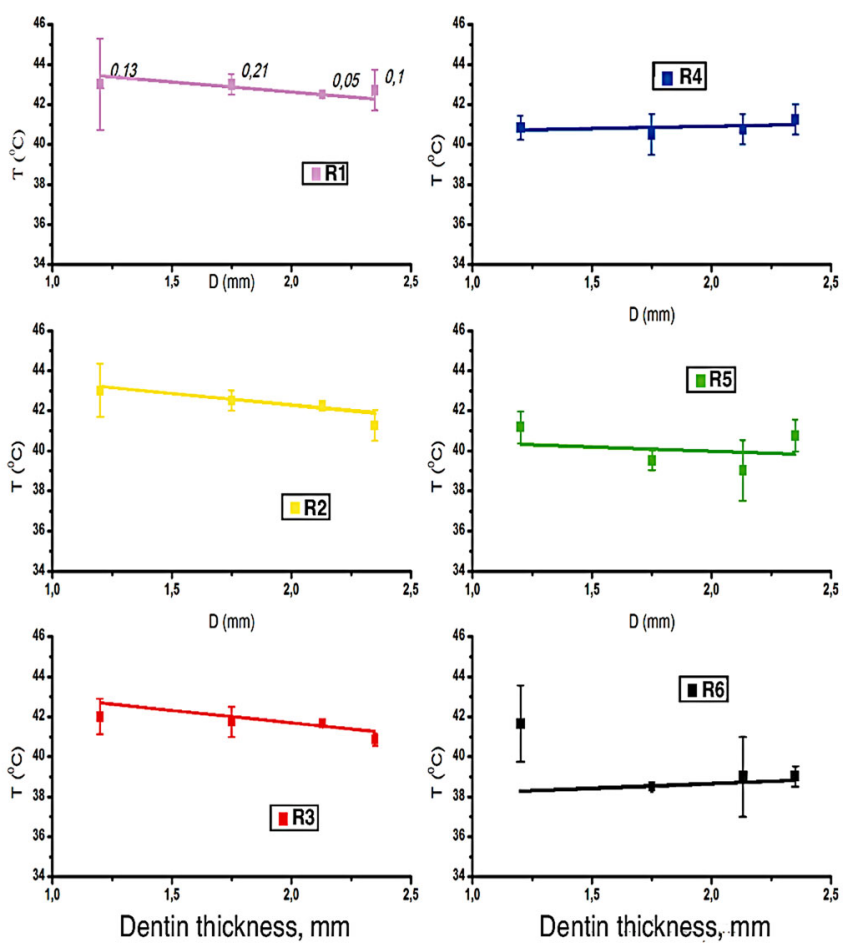

The values of overheating diminish with increase of root dentin thickness and are different for each of the three techniques.

During mechanical root-canal preparation with different No. No. files, the values of overheating are low and they couldn't cause damages of periradicular tissues (the values don't exceed $3-4^{\circ} \mathrm{C}$ in our study).

During root-canal obturation with warm condensation techniques with gutta-percha, when the heating continue more than 5-6 seconds is possible that the temperature values to reach $47-48^{\circ} \mathrm{C}$ (increasing with $10-11^{\circ} \mathrm{C}$ ). This temperature could injure the periradicular tissues and alveolar bone(fig.3). The risk is bigger for teeth with fine roots (lower incisors and premolars) - the thickness of root dentin of these teeth is under 1,5-2 $\mathrm{mm}$.

During root-canal preparation for radicular posts are determined higher values of overheating when the smaller reamers are used No.No. 1, 2- up to $8-9^{\circ} \mathrm{C}$ (to $45^{\circ} \mathrm{C}$ ) and when the prepared teeth are with fine roots. This probably is associated with the fact that with the smaller reamers is taken off more dentin for unit time; the risk of overheating is bigger in initial stage of preparation.

\section{CONCLUSION}

The results of our study showed, that during warm condensation with System B and during initial stage of rootcanal preparation for radicular post could be achieve overheating of external root surface over the critical level-from 6-7 to $10-11^{\circ} \mathrm{C}$.It's necessary that we work with great attention, with precise dosage of the time of manipulation and cooling the dentin. It's recommended the use of devices for warm condensation with fixed time of heating up to 5 seconds. The break between the heating should be $10-$ 15 seconds.

During root-canal obturation with Obtura II the temperature raising is lower and there is no risk of injury.

The root canal preparation for intraradicular posts should be done with new instruments at slow-motion of endodontic handpieces.

When we prepare teeth with fine roots, the risk of overheating is bigger.

For exact control of overheating during thermal manipulation during endodontic treatment we need in vivo studies with modern technique, such as infrared thermal imaging camera. 


\section{REFERENCES:}

1. Behnia A, McDonald NJ. In vitro infrared thermographic assessment of root surface temperatures generated by the thermafil plus system. J Endod. 2001 Mar;27(3):203-5. [PubMed] [CrossRef]

2. Hussey DL, Biagioni PA, McCullagh JJ, Lamey PJ. Thermographic assessment of heat generated on the root surface during post space preparation. Int Endod J. 1997 May; 30(3):187-90. [PubMed] [CrossRef]

3. Lipski M. Root surface tempera- ture rises during root canal obturation, in vitro, by the continuous wave of condensation technique using System B HeatSource. Oral Surg Oral Med Oral Pathol Oral Radiol Endod. 2005 Apr;99(4):505-10. [PubMed] [CrossRef]

4. Saunders EM, Saunders WP. The heat generated on the external root surface during post space preparation. Int Endod J. 1989 Jul;22(4):169-73. [PubMed] [CrossRef]

5. Tjan AH, Abbate MF. Temperature rise at root surface during post-space preparation. J Prosthet Dent. 1993 Jan;69(1):41-5. [PubMed] [CrossRef]

6. Venturi M, Pasquantonio G, Falconi M, Breschi L. Temperature change within gutta-percha induced by the System-B Heat Source. Int Endod J. 2002 Sep;35(9):740-6. [PubMed] [CrossRef]

7. Weller RN, Koch KA. In vitro radicular temperatures produced by injectable thermoplasticized guttapercha. Int Endod J. 1995 Mar;28(2): 86-90. [PubMed] [CrossRef]

\section{Address for correspondence:}

Tzvetelina Gueorgieva

Department of Operative dentistry and Endodontics, Faculty of Dental Medicine, Medical University - Sofia, 